\title{
Science and industry evolution: evidence from the first 50 years of the German laser industry
}

\author{
Guido Buenstorf • Dominik P. Heinisch
}

Accepted: 23 February 2018/Published online: 11 April 2018

(C) The Author(s) 2018

\begin{abstract}
Industry evolution is driven by innovation. Scientific research is an important source of innovation-relevant knowledge. To trace its impact on industry evolution, we follow the entry and exit of firms from various backgrounds over the first five decades of the German laser industry. We find that academic startups became increasingly competitive after substantial changes were introduced to the governance of university-industry relationships. Their enhanced performance helps explain why no shakeout in firm numbers has been observed to date. Doctorateholding inventors contributed to the performance of
\end{abstract}

\footnotetext{
G. Buenstorf $(\bowtie)$

University of Kassel, Kassel, Germany

e-mail: buenstorf@uni-kassel.de

G. Buenstorf · D. P. Heinisch

INCHER, Kassel, Germany

D. P. Heinisch

e-mail: heinisch@uni-kassel.de

G. Buenstorf

Institute of Innovation and Entrepreneurship,

University of Gothenburg, Gothenburg, Sweden

G. Buenstorf

IWH Leibniz Institute of Economics Halle, Halle, Germany

G. Buenstorf · D. P. Heinisch

Institute of Economics, University of Kassel,

Moenchebergstrasse 17, 34109 Kassel, Germany
}

entrants, indicating that the impact of scientific knowledge on industry evolution goes beyond academic entrepreneurship.

Keywords Industry evolution · Scientific knowledge $\cdot$ Academic entrepreneurship $\cdot$ Doctoral training $\cdot$ Laser

JEL classification $\mathrm{L} 10 \cdot \mathrm{L} 26 \cdot \mathrm{I} 23 \cdot \mathrm{O} 33$

\section{Introduction}

Laser manufacturing is a prime example of a sciencebased industry (Grupp 2000). Following a prolonged race involving universities, governmental research facilities, and corporate R\&D laboratories, the first workable laser was built in 1960 (Bromberg 1991). Within a few years, commercial laser manufacturers entered the US market, often directly drawing on prior research efforts. Subsequently, the size of the US laser firm population continued to increase for several decades (Klepper and Sleeper 2005). New entrants came from various backgrounds. Besides diversifying pre-existing firms from high-tech sectors such as aerospace and defense, they included academic entrepreneurs from universities and government labs as well as intra-industry spin-offs, i.e., entrepreneurial firms started by individuals who had previously worked for laser firms. Defying the regularities of the industry life cycle (Klepper 1997), 
Fig. 1 Evolution of the German laser industry (source: own compilation)

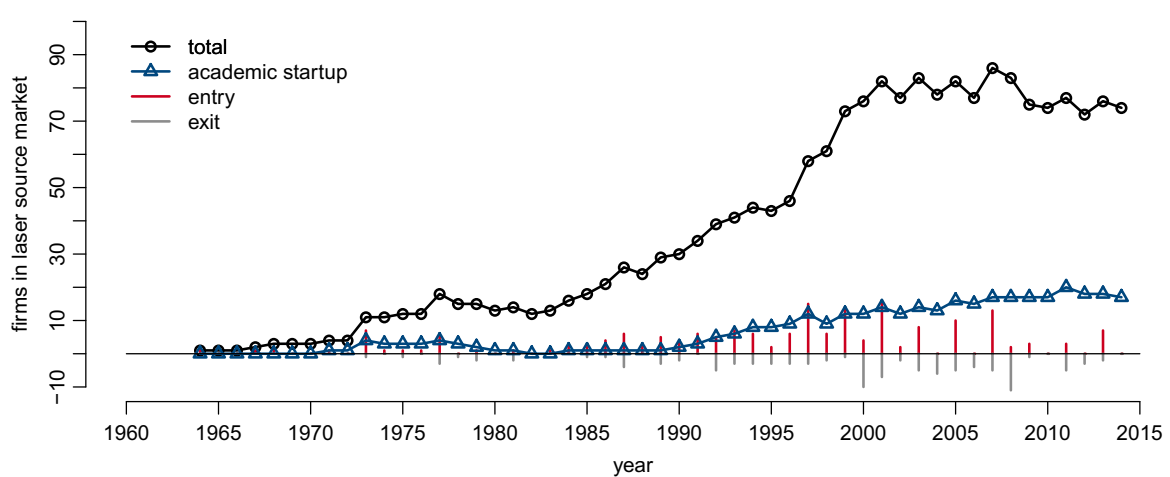

a shakeout in the number of active US producers only set in after about 35 years, much later than in most other industries. This shakeout had a pronounced effect on the firm population. From 1996 to 2007, the number of US laser producers fell by about $50 \%$ (from 172 to 87). Bhaskarabhatla and Klepper (2014) relate this drastic decrease to a major upheaval in laser technology: the diode-pumped solid state (DPSS) laser that replaced earlier laser types in a variety of applications.

The development of the German laser industry exhibits a number of parallels to the USA. Early entry drew on direct or indirect links to laser research (Albrecht 1997), and an almost uninterrupted increase in the number of active firms was observed for decades (Buenstorf 2007). Academic entrepreneurship andto an even larger extent-intra-industry spin-offs were also widespread in the German laser industry (ibid.). This is notable because in the 1970s and 1980s, Germany was characterized by a weaker entrepreneurial culture, a less developed venture capital industry, and stronger legal restrictions to employee mobility than the USA and especially California (where many US laser producers were located) - factors that have been shown to affect the prevalence and success of entrepreneurial activities (Beugelsdijk 2007; Marx et al. 2009; Samila and Sorenson 2011; Fritsch and Wyrwich 2014). More recently, however, the German laser industry has taken a different path from that of the US industry. No significant decrease in firm population size has been observed, but firm numbers have stabilized in the late 1990s (cf. Fig. 1). New entrants have continued to replenish the firm population, compensating for incumbents that failed, were acquired, or decided to concentrate on other markets. This absence of a shakeout after 50 years of evolution constitutes a remarkable deviation from the pattern generally observed in industry evolution (Klepper 1997; Buenstorf 2007).

The objective of this paper is to study the recent evolution of the German laser industry in more detail. Motivated by the science-based nature of the industry, we particularly focus on the potential role of scientific $^{1}$ knowledge. In line with prior work on industry evolution, we first trace recent entries and exits and how they affected the composition of the firm population in terms of pre-entry experience. We identify new entrants based on academic entrepreneurship and compare their longevity in the laser industry with that of other types of entrants. However, just tracing academic startups does not fully account for the impact of scientific knowledge on industry evolution. Entrepreneurs with other preentry backgrounds may also have acquired scientific knowledge, and university-educated employees further add to the firms' knowledge stocks. We therefore identify doctorate holders among spin-off founders and corporate inventors and analyze their impact on firm longevity, thus contributing to the understanding of how the backgrounds and early hires of entrepreneurial entrants shape the evolution of innovative industries. With doctoral training, we address a potentially powerful channel of transferring academic knowledge to the private sector that still is not sufficiently well understood, and for which consistent information can be assessed over long periods of time.

The remainder of the paper is structured as follows. In Section 2, we discuss the theoretical and institutional background of the study. Section 3 details the

\footnotetext{
${ }^{1}$ In what follows, "scientific" will be used as a generic term that also covers engineering research.
} 
data collection for the empirical analysis. Section 4 studies the performance of different types of entrants in the evolution of the German laser industry, focusing on academic entrepreneurship and inventors with doctoral training. Section 5 concludes.

\section{Theoretical background: industry evolution, entrepreneurship, and science}

\subsection{The evolution of firm populations in innovative industries}

A sizeable literature explores empirical regularities in the evolution of industries (cf., e.g., Klepper (1997); and Peltoniemi (2011) for surveys). The key stylized fact established in this literature is that industries ${ }^{2}$ tend to experience a shakeout in the number of active firms. Characteristically, the shakeout is observed at an early age of the industry when its output is still growing. It turns an atomistic market structure with many small producers into an oligopolistic one dominated by a few large firms. A prominent case in point is the US automobile industry where the shakeout began in 1907, the year before Ford introduced the Model $\mathrm{T}$ that would spur mass motorization and the phenomenal growth of the industry. Within 16 years, the number of active firms was reduced by $60 \%$, only to fall further afterwards.

According to the leading models of industry evolution, firm population dynamics are driven by technological developments in terms of product (Utterback and Suảrez 1993) or process innovation (Jovanovic and MacDonald 1994; Klepper 1996, 2002). In Klepper's evolutionary model, the shakeout emerges from differences in firms' ability to spread the fixed cost of process innovation over their output base (Cohen and Klepper 1996). Cost spreading induces an escalation of R\&D efforts (Sutton 1998) and gives rise to success-breeds-success dynamics favoring large and early entrants. Eventually, profitable entry is no longer feasible and smaller incumbents (which often entered late) are driven from the market.

\footnotetext{
${ }^{2}$ In the literature on industry evolution, industries are narrowly defined, typically corresponding to individual product markets such as automobiles, disk drives, or semiconductors. The laser industry has been studied in this literature ever since Gort and Klepper (1982).
}

Not all industries experience a shakeout, and not all at the same age. Variations in the evolutionary dynamics of industries have been linked to the heterogeneity of product designs. In particular, in industries whose product is made in many variants that are poor substitutes, individual submarkets may be too small to induce an escalation of R\&D efforts. Small producers may then remain competitive, market structure may remain atomistic, and profitable entry may be feasible for decades. According to Bhaskarabhatla and Klepper (2014), this description fits the early US laser industry. Before the diode-pumped solid-state (DPSS) laser, individual laser types could hardly be substituted for each other because they differed in wavelength, maximum power, and other user-relevant characteristics. In essence, each application required a specific type of laser. Pre-DPSS, lasers for individual applications were often made by a small number of producers, and most producers were only active in a few application markets. New laser designs opened up new applications and allowed for the entry of new producers, which often faced little competition from incumbents. Beginning in the late 1980s, however, DPSS lasers were becoming available that were more versatile in use and began to compete with other laser types. Bhaskarabhatla and Klepper (2014) suggest that the DPSS market was large enough to warrant cost-reducing process innovations. An $R \& D$ escalation set in, which challenged smaller DPSS producers while further increasing DPSS competitiveness vis-àvis other laser types. This gave rise to a shakeout first in the DPSS market, then in the US laser industry more generally.

Based on the interest in industry evolution, a related literature focuses on the composition of entry cohorts in different industries and on how pre-entry experience relates to post-entry performance (cf. Helfat and Liebermann (2002)). Two types of entrants have been in the focus of this literature: diversifiers from related industries and intra-industry spin-offs. Both types of entrants figured prominently in the laser industry. Similar to other industries, they tended to outcompete firms with alternative types of pre-entry experience (Sleeper 1998; Buenstorf 2007).

The distinctive performance of diversifiers and spin-offs suggests that capabilities can be reproduced and transferred across markets and organizations. Spin-off dynamics can be conceptualized as an evolutionary process in which spin-offs inherit capabilities 
and the underlying organizational routines (Nelson and Winter 1982) from their parent firms (Klepper 2001, 2016). This distinctively evolutionary process is relevant beyond individual industries because it shapes the composition of national and regional economies and induces path-dependent development trajectories (Frenken and Boschma 2012), which is corroborated by findings on national product portfolios (Hidalgo et al. 2007), regional clustering (Buenstorf and Klepper 2010), and the branching of industries (Neffke et al. 2011). Pinning down exactly what is inherited has remained elusive, however. Likewise, we do not fully understand how industry evolution is shaped by the context of the industry.

\subsection{Academic entrepreneurship and industry evolution}

Industry evolution does not happen in isolation but is shaped by the industry's environment. Scientific research is an important part of this environment. The literature on university-industry relationships indicates that science may shape industry evolution through a number of channels of impact and various forms of scientist engagement (cf., e.g., Perkmann et al. (2013)). Traces of science are easily found in the laser industry. Not only did the laser originate from scientific research activities. Science continued to affect the laser industry throughout its subsequent evolution.

Academic entrepreneurship generating new entrants is perhaps the most direct channel through which science affects industry evolution (Heblich and Slavtchev 2014). It is quite significant in the laser industry. Academic entrepreneurs from universities and government labs accounted for $9 \%$ of all US laser entrants from 1991 to 1994 . They were the third largest group of entrants, surpassed only by diversifiers $(60 \%)$ and intra-industry spin-offs (16\%). In Germany, about $20 \%$ of all laser entrants before 2003 were based on academic entrepreneurship (where the larger share is mostly due to a smaller number of diversifying entrants than in the USA). Even though early academic laser startups were mostly outperformed by diversifiers and spin-offs (Sleeper 1998; Buenstorf 2007), individual success stories exist. In Germany, they include Lambda Physik, which pioneered excimer lasers and became one of the industry's early leaders. Lambda Physik went public in 2000 and was eventually acquired by Coherent, one of the major US laser producers.

Academic entrepreneurship is generally recognized as a relevant field of innovation policy today, and public support schemes have been established to foster academic entrepreneurship. This is a relatively recent development, however, which started well after the beginning of the laser industry. The main instrument to support academic entrepreneurship in Germany is the EXIST program initiated by the federal government in 1998 (Kulicke 2014). EXIST combines the funding of measures fostering a more entrepreneurial culture at German universities with (since 2000) personal support for (nascent) academic entrepreneurs. It has been complemented by policy measures at the level of individual federal Länder. Availability of venture capital for academic entrepreneurs was increased when the High-Tech Gründerfonds (HTGF), a privatepublic partnership that has grown into Germany's most important seed-stage investor, was established in 2005.

Initiatives to enhance knowledge and technology transfer from universities have accompanied the support of academic entrepreneurship. New infrastructure for technology transfer offices was put into place, and inventor ownership of academic patents was replaced by university ownership, in 2002 . While the available empirical evidence does not suggest that these reforms resulted in larger numbers of academic patents, they seem to have increased the likelihood that academic patenting leads to entrepreneurial activity (Czarnitzki et al. 2016).

Through their various initiatives, German policy makers hoped to increase the number and quality of startups from universities and public research organizations. If successful, the effects of these initiatives should be particularly pronounced in science-based industries such as laser manufacturing. One might therefore expect to find increasing numbers, as well as an enhanced performance, of academic startups when they gained the support of public policy. We will explore this conjecture below.

\subsection{Doctoral training of corporate inventors and entrepreneurs}

Accounting for academic start-ups is not sufficient to fully capture the role of scientific knowledge in industry evolution. Science does not only provide a seedbed 
for new firms, but also impacts on established ones. Various forms of academic engagement with the private sector (Perkmann et al. 2013) have also been in the focus of recent public policy initiatives, and the German laser industry was a preferred target of these initiatives. From its beginning, policy makers considered laser technology to be of strategic importance for the German manufacturing sector, and a succession of large-scale programs addressed laser research (Albrecht 1997). Not least due to the active lobbying of the laser industry itself, these programs often focused on industrial applications and collaboration with private-sector partners (Fabian 2011). ${ }^{3}$

As German universities use large shares of their grant money to employ doctoral students in the funded projects, doctoral training is an important outcome of research funding. The majority of graduated doctoral students subsequently work in the private sector, often in corporate R\&D laboratories. Their mobility constitutes an important channel through which scientific knowledge is disseminated. As shown by Zellner (2003), graduates from doctoral training not only bring up-to-date knowledge about their specific field to their private-sector employment. Analytical problem-solving skills and familiarity with the broader discipline seem even more important. Embodied knowledge transfer based on graduate mobility also provides firms with access to tacit research skills, which are difficult to acquire from publications and patents.

Recent work shows that the quality of early employees is an important factor in the performance of entrepreneurial entrants (e.g., Dahl and Klepper (2015)). We follow numerous earlier studies and use patent data to identify inventors working for laser producers. Based on an intricate matching procedure (see Section 3 for details), we are able to distinguish corporate inventors who hold doctoral degrees from those who do not. This allows us to study whether the (early)

\footnotetext{
$\overline{{ }^{3} \text { Tracing R\&D }}$ collaboration in patents and scientific publications is difficult, particularly over large periods of time. Based on limited data, Blankenberg and Buenstorf (2016) find only modest numbers of co-authored papers and co-invented patents in German laser research. Buenstorf et al. (2015) as well as Fritsch and Medrano Echalar (2015) find that public research and private-sector laser activities are positively related at the regional level.
}

hiring of R\&D staff with doctoral research training is systematically associated with the performance of entrants.

Information about doctoral training moreover allows for a more fine-grained approach to trace the role of scientific knowledge in the pre-entry experience of entrants. By identifying entrepreneurs with doctoral degrees, we begin to disentangle founder education from pre-entry job experience in accounting for the performance of entrants. Not all academic entrepreneurs in our firm dataset hold doctoral degrees, but a number of academic startups were organized by technical staff or graduates of master programs. Nor is doctoral training limited to academic entrepreneurs. Founders of intra-industry spin-offs often completed doctoral training before they started to work for laser incumbents. We also observe diversifiers whose founders hold doctoral degrees and still influence the laser activities of the firm.

\section{Data}

3.1 Entry, exit, and pre-entry experience in the German laser firm population, 1964-2013

To trace the recent evolution of the German laser firm population, we extended the dataset assembled by Buenstorf (2007) to the year 2013. Given that the first entrant was observed in 1964, this provides us with data for the full population of commercial laser source producers in Germany over the first 50 years of the industry. The extension is based on the same data sources and classification principles as the original dataset. In particular, we employed the catalogs of the biannual LASER trade fair in Munich, as well as annual buyers' guides, to identify new entrants after 2003 as well as firms that exited from the laser market. The extended dataset covers 184 firms active from 1964 to 2013. It is restricted to domestic producers of laser sources and does not include importers or mere distributors. Laser system producers without own production and sales of laser sources are also excluded.

Again replicating earlier efforts, we then identified the pre-entry experience of the post-2003 entrants. For diversifiers, we recorded their backgrounds in other industries. De novo entrants were classified into three broad categories: intra-industry spin-offs 
started by individuals with work experience in the laser industry (including serial laser entrepreneurs), academic startups started by individuals coming from universities and other public research organizations (researchers, technical staff, as well as students), and a small group of other startups including all remaining entrepreneurial entrants. Firm and founder backgrounds were established on the basis of all available information, including laser trade magazines and other publications, firm websites, incorporation files, and professional online networks.

The German laser firm population has been characterized by substantial heterogeneity throughout its evolution. German laser producers are active in many different application markets. They are best known for industrial materials-processing lasers, but also supply lasers for metering, signal processing, scientific research, and other applications. Many produce not only laser sources but also systems incorporating these sources (Buenstorf et al. 2015). The available evidence moreover suggests that firm sizes are highly skewed. Some laser producers are large diversified corporations, but the majority is small. The ownership structure is likewise heterogeneous; it includes many family-owned companies. As indicated by the example of Trumpf Group, one of the world's leading makers of industrial laser sources and systems, family-owned firms can grow into global players of substantial size. (Trumpf currently has more than 10,000 employees, and about two-thirds of sales are related to lasers; cf. Trumpf Group (2016).) Laser firms are located all over Germany, with pronounced clusters in and around Munich and Berlin. Notably, the laser industry is one of the few high-tech industries with a meaningful presence in Eastern Germany. This reflects the long-term legacy of the optical industry in this region, but also the substantial success that socialist East Germany had in laser research before Germany was united in 1990 (Albrecht 1997).

\subsection{Identifying corporate inventors and entrepreneurs with completed doctoral training}

A series of data collection, matching, and disambiguation steps were required to extend the firmlevel dataset to the level of individual inventors and entrepreneurs. As a first step, we collected the names of all inventors listed on patents by laser source producers. To this purpose, all laser-related priority patent applications ${ }^{4}$ filed by German applicants were retrieved from PATSTAT (2014 Autumn Edition), a total of 12,134 patents for the time period 1960 to 2012. Laser source producers among the applicants were identified using an extended list of firm names that includes several name variants of the 184 firms in our firm-level dataset. Standardized applicant and firm names (and where available previous or alternative firm names) were matched using a fuzzy string matching algorithm. ${ }^{5}$ Matches were manually checked for false positives. A total of 110 firms included in the list were identified as having filed at least one patent. They account for 4189 patent applications or about $35 \%$ of all patents in the respective classes, reflecting substantial laser-related patenting of large manufacturing firms that are not commercial laser source producers. To ensure completeness of firms' patent portfolios, the above procedure was repeated for the firm founders. Entrepreneurs may have applied for patents before they started their own firms, which may then not be listed as patents of the respective firms. Altogether, information is available on 244 founders. Applying the above matching procedure resulted in 128 additional patent applications filed by 52 founders.

We next identified laser inventors and entrepreneurs with completed doctoral training. To this purpose, we matched inventor names with the author names of all laser-related doctoral dissertations submitted to German universities (1970-2015). Six thousand four hundred seventeen distinct inventor names are listed on the patent applications in the sample. Inventor names were cleaned and academic titles listed in the patents were retrieved. Since the "Dr." is an official part of the name in Germany, it is also frequently found in patent documents. The set of inventor names was disambiguated using information on common co-inventors, applicants, addresses, and titles. This procedure identified 2794 unique inventors whom we

\footnotetext{
${ }^{4}$ We selected all patents filed by German applicants in IPC "H01S" and "B23K 26" and their subclasses. We also included patents filed in IPC, "A61B 18/2," "A61F 9/008," "A61F 9/009," "A61N 5/068," "A62D 3/17," "B22F 3/105," "B23H 7/38," "B29C 65/16," “B41J 2/455," "F21K 9/00," "F21Y 115/30," “G01C 19/66," “G01N 21," "G02B 27/48," "G11B 7/127," and "G11B 11/03" whenever the patent title contained "laser".

${ }^{5}$ For all string matchings, a 2-gram Jaccard similarity was employed as proposed by Schoen et al. (2014) for German patent data. We use a threshold of 0.8 because our sample allows for manual data checking.
} 
Table 1 Descriptive statistics

\begin{tabular}{|c|c|c|c|c|c|c|c|c|}
\hline & \multicolumn{2}{|c|}{ Diversifier } & \multicolumn{2}{|c|}{ Spin-off } & \multicolumn{2}{|c|}{ Acad. startup } & \multicolumn{2}{|l|}{ Others } \\
\hline Firms (total) & 59 & & 71 & & 41 & & 13 & \\
\hline Firms founded post 1997 & 26 & & 44 & & 25 & & 8 & \\
\hline Firms patenting & 36 & & 41 & & 27 & & 6 & \\
\hline Average patents & 62.76 & $(240.93)$ & 5.82 & $(13.2)$ & 10.76 & $(39.75)$ & 1.15 & $(1.77)$ \\
\hline Average patents pre-entry & 3.22 & $(6.65)$ & 1.65 & $(5.87)$ & 2.02 & $(4.38)$ & 0.46 & $(1.13)$ \\
\hline Founder is patenting & 0.17 & $(0.38)$ & 0.3 & $(0.46)$ & 0.44 & $(0.5)$ & 0.23 & $(0.44)$ \\
\hline Founder is $\mathrm{PhD}$ & 0.25 & $(0.44)$ & 0.46 & $(0.5)$ & 0.85 & $(0.36)$ & 0.31 & $(0.48)$ \\
\hline Inventors (pre-entry) & 2.32 & $(6.26)$ & 1.55 & $(5.59)$ & 1.8 & $(2.93)$ & 0.15 & $(0.38)$ \\
\hline PhD inventors (pre-entry) & 0.32 & $(0.8)$ & 0.45 & $(1.38)$ & 0.78 & (1.74) & 0.08 & $(0.28)$ \\
\hline
\end{tabular}

Rows one to four report number of firms, rows four to nine report averages (standard deviation in parentheses)

matched against the full list of dissertation authors listed in the catalog of the Deutsche Nationalbibliothek (DNB). Since 1969, the DNB has had a legal mandate to collect all doctoral dissertations defended in Germany. For our matching, we consider all dissertations in physics, electrical engineering, and mechanical engineering listed in the DNB catalog. Medical dissertations were excluded. The final dataset contains 152,679 dissertations and their authors.

Several filters were applied to identify false-positive matches. These filters include information on laserrelated titles and unique author names. Dissertations were classified as laser-related if the title includes words strongly suggesting an association with laser research. ${ }^{6}$ For all matched dissertation authors, homonyms were searched in the dissertation sample. If no homonym (dissertation author with exactly the same combination of first and family names) was found, the respective individual was classified as having a unique name. In other words, they are the only person of this specific name holding a doctoral degree from a German university in one of the relevant disciplines. Combined with a "Dr." in the inventor name data, a unique name is a strong predictor of a true positive match. In addition, the lag between the year of graduation and the year of the first patent filing was calculated. All positive-matched inventor-author pairs were manually processed to detect false name matchings.

\footnotetext{
${ }^{6}$ The following words were classified as indicating laser science-related dissertations: "laser," "light," "spectroscopy," "spectral," "pulse," "optical," "induced," and their German translations.
}

Additional information was used in cases where no clear-cut decision was possible. After eliminating falsepositive-matched author-inventor pairs, we obtained 665 inventors with completed doctoral training who patented for German laser source producers. By applying the same procedure to the 244 laser firm founders, 86 entrepreneurs were identified to hold a doctoral degree.

Table 1 provides descriptive statistics of the main variables used in the empirical analysis below. Table 2 contains pairwise correlations.

\section{Empirical analysis}

4.1 Academic startups in the evolution of the German laser industry

The updated dataset covering the full firm population of the German laser industry over its first five decades provides a rare opportunity to study the long-term evolution of a contemporary science-based industry. It also allows us to explore the impact of scientific knowledge on this evolution, as well as how this impact may have changed over time. As noted above, the recent evolution of the firm population in the German laser industry differed from what might have been expected when using the US industry as a benchmark. Given the modified governance of university-industry relations in Germany, changes in the use of scientific knowledge in entrepreneurship and innovation plausibly contributed to the divergent development. To begin to explore this conjecture, in this subsection, 
Table 2 Correlation matrix

\begin{tabular}{|c|c|c|c|c|c|c|c|c|c|c|c|}
\hline & (1) & (2) & (3) & (4) & $(5)$ & (6) & (7) & (8) & (9) & (10) & (11) \\
\hline Spin-off & 1 & -0.42 & -0.54 & 0.09 & -0.11 & -0.07 & 0.02 & -0.01 & -0.03 & 0 & 0.05 \\
\hline Acad. startup & & 1 & -0.37 & 0.07 & -0.05 & -0.01 & 0.19 & 0.41 & 0.01 & 0.14 & 0.04 \\
\hline Diversifier & & & 1 & -0.19 & 0.19 & 0.13 & -0.17 & -0.3 & 0.08 & -0.07 & -0.12 \\
\hline Entry year & & & & 1 & -0.29 & -0.12 & 0.19 & 0.3 & 0.02 & 0.13 & 0.76 \\
\hline Average patents & & & & & 1 & 0.53 & -0.06 & -0.11 & 0.35 & 0.08 & -0.14 \\
\hline Average patents pre-entry & & & & & & 1 & 0.16 & -0.09 & 0.76 & 0.54 & -0.1 \\
\hline Founder is patenting & & & & & & & 1 & 0.3 & 0.19 & 0.26 & 0.1 \\
\hline Founder is $\mathrm{PhD}$ & & & & & & & & 1 & -0.07 & 0.11 & 0.25 \\
\hline Inventors (pre-entry) & & & & & & & & & 1 & 0.69 & -0.02 \\
\hline $\mathrm{PhD}$ inventors (pre-entry) & & & & & & & & & & 1 & 0.08 \\
\hline Founded post-1997 & & & & & & & & & & & 1 \\
\hline
\end{tabular}

we trace changes in the composition of entry and the performance of entrants. In the next subsection, we will investigate the role of inventors and entrepreneurs with doctoral training.

Bhaskarabhatla and Klepper (2014) date the beginning of the US shakeout to 1996. In our data for Germany, the number of active laser firms increased until 2001, and no clear-cut trend in the number of active firms is discernible in later years. In the following analysis, we will distinguish two phases of the German laser industry. We define the second phase as the time period when, based on the US experience, a shakeout might have been expected to occur in Germany. Specifically, we use 1998 as the beginning of this second phase, i.e., 2 years after the US shakeout had started and 3 years before the continual growth of the German firm population ceased. The year 1988 also was the starting year of the EXIST program, which marks a watershed in the support for academic entrepreneurship (Egeln et al. (2010); cf. also Section 2).

As can be seen in Table 1, about half of all academic startups entered in the post-1997 period. Academic startups account for $24 \%$ of all entrants in this period vs. $20 \%$ in the first period. On first glimpse, this modest increase seems to suggest that the changing governance of university-industry relations did not have a strong effect on academic startups. Note, however, that their share among all active firms in the laser industry tended to increase throughout the post1997 period (Fig. 1). This indicates that, counter to prior findings for the earlier years of the German laser industry, academic startups entering in the second period performed relatively well.

To study the performance of entrants in a more systematic way, we use longevity in the laser industry as a proxy of firm performance and perform hazard rate models specified in similar ways as in Buenstorf (2007). As has often been observed (e.g., Lieberman and Montgomery (2013) and Weterings and Marsili (2015)), longevity is an imperfect measure of firm performance. Remaining in the market indicates only that a minimal level of performance is attained, while there tend to be pronounced differences in growth and profitability among the firms that remain active in a market. Even though these differences are not captured in hazard rate models, hazard rate analyses are nonetheless in widespread use in the literature on industry evolution. This is owed to the lack of alternative performance indicators that can be assessed for the full population of firms, including those which are too small to be required to disclose financial information or employee numbers, over long periods of observation. We face the same problems for the German laser industry, which includes many small firms that have ceased to exist long ago and for which no information about size or profits can be retrieved.

Another shortcoming of longevity as a performance indicator is that firms may exit for a variety of reasons which are not equally informative about performance (or the lack thereof). Exit by merger of acquisition is particularly worrisome. Being acquired may allow poor performers to avoid impending bankruptcy. Alternatively, 
it may reflect success, as up-and-coming firms are taken over by larger competitors or industry outsiders. The acquisition may then allow these promising firms to finance their further growth. In the literature on industry evolution, the conventional approach to deal with the ambiguous nature of acquisitions is to handle firms acquired by competitors, as well as smaller partners in merger events, as censored observations (e.g., Klepper (2002)). Censoring makes full use of the information about the firm's survival up to the acquisition event, while allowing the researcher to remain agnostic about the cause of being acquired. We adopt the same approach in our empirical analysis. We also follow prior practice (ibid.; Buenstorf (2007)) in specifying the hazard models as parametric Gompertz models assuming proportionality of hazards across types of entrants.

The first set of results from these models is reported as Models 1-3 (Table 3). Model 1 only includes

Table 3 Exit of German laser source producers, 1964-2013

Proportional hazard rate models (Gompertz specification)

(1)

(2)

(3)

\begin{tabular}{lccc}
\hline Diversifier & -0.42 & & $-0.69^{\mathrm{b}}$ \\
& $(0.29)$ & & $(0.30)$ \\
Spin-off & -0.30 & & $-0.58^{\mathrm{b}}$ \\
& $(0.27)$ & & $(0.28)$ \\
Academic startup & & $0.66^{\mathrm{a}}$ & \\
& & $(0.34)$ & \\
Post 1997 & & 0.02 & \\
& & $(0.27)$ & \\
acad_post & & $-1.18^{\mathrm{a}}$ & \\
& & $(0.64)$ & \\
Academic startup (post 1997) & & & $-1.08^{\mathrm{b}}$ \\
& & & $(0.54)$ \\
Constant & & & $-2.60^{\mathrm{c}}$ \\
& & & \\
& & & \\
Duration & $-2.90^{\mathrm{c}}$ & $-3.18^{\mathrm{c}}$ & \\
& $(0.22)$ & $(0.21)$ & $(0.24)$ \\
& -0.01 & -0.01 & -0.01 \\
Time at risk & $(0.02)$ & $(0.02)$ & $(0.02)$ \\
Events & & & \\
Firms & & & \\
log Lik & 1943 & 1943 & 1943 \\
\hline
\end{tabular}

Robust standard errors in parentheses

${ }^{\mathrm{a}} p<0.1 ;{ }^{\mathrm{b}} p<0.05 ;{ }^{\mathrm{c}} p<0.01$ two dummy variables denoting diversifiers and intraindustry spin-offs, respectively. Negative but insignificant coefficient estimates are obtained for both variables. Accordingly, in contrast to Buenstorf (2007), we do not find systematic differences in exit hazards across the various types of entrants. Consistent with Buenstorf (2007), no systematic duration dependence of hazard rates is indicated by our results. In other words, entrants are not subject to a significant liability of newness (Stinchcombe 1965).

In Model 2, we investigate how the exit hazard developed over time, with a focus on academic startups. The model includes a dummy variable indicating academic startups, a second dummy variable denoting post-1997 entrants, and an interaction between both. Two aspects of the results are noteworthy. On the one hand, we do not find that post-1997 entrants generally had a lower exit hazard. The coefficient estimate of the post-1997 dummy is very close to zero and far from being statistically significant. On the other hand, the exit hazard of academic startups differs drastically between the two periods. While early academic startups perform significantly worse than other entrants, we estimate a much smaller coefficient for the late academic startups (significant at the $10 \%$ level) implying a reduction in the hazard of about $70 \%$ between the two cohorts of academic startups. These results suggest a positive development in the longevity of entrants after 1997, which however was restricted to academic startups.

Model 3 corroborates these findings. It differs from Model 1 only in that a further dummy variable denoting post-1997 academic startups is added. The coefficient estimated for this variable implies a $64 \%$ lower hazard compared to the reference group of early academic startups and other entrants. This compares to a $50 \%$ reduced hazard of diversifiers and a $44 \%$ reduced hazard of spin-offs (irrespective of their entry year) and indicates that, different from their earlier peers, late academic startups were similarly successful as diversifiers and spin-offs. ${ }^{7}$ The log-likelihood of Model 3 is significantly above that of Model 1, indicating that separating the two cohorts of academic startups improves our ability to explain exit hazards. We thus conclude that the inferior performance of

\footnotetext{
${ }^{7}$ Differences between the respective coefficient estimates are not statistically significant at conventional levels.
} 
academic startups reported by Buenstorf (2007) is limited to the first cohort. In contrast, post-1997 academic startups were able to compete successfully with other types of entrants.

4.2 Doctoral research training and the performance of entrants

The above results point to an increasing competitiveness of academic startups after 1997, which might provide some justification to the recent policy efforts toward academic entrepreneurship in Germany. However, as discussed above, not only academic startups utilize scientific knowledge. In particular, we expect that entrants of all types may benefit from having founders and inventors trained in scientific research.

To test the relevance of founders' scientific knowledge, we distinguish spin-offs with at least one founder who holds a doctoral degree from all other spin-offs (Model 4 in Table 4). This provides no support for our conjecture, as we do not find a significant difference in the exit hazards of both groups. Model 5 is another variant of Model 3 featuring two new variables. "Opportunity entrepreneur" uses pre-entry patents held by the firm's founder as a proxy of opportunity entrepreneurship, i.e., entry primarily driven by the motivation to exploit a business opportunity rather than induced by external factors such as job loss or deteriorating
Table 4 Exit of German laser source producers, 1964-2013 (continued)
Estimates from proportional hazard rate models (Gompertz specification)

(4) (5) (6)

\begin{tabular}{|c|c|c|c|c|}
\hline & & & & \\
\hline Diversifier & $\begin{array}{c}-0.69^{\mathrm{b}} \\
(0.30)\end{array}$ & $\begin{array}{c}-0.75^{\mathrm{b}} \\
(0.30)\end{array}$ & $\begin{array}{c}-0.64^{b} \\
(0.31)\end{array}$ & $\begin{array}{c}-0.60^{\mathrm{b}} \\
(0.30)\end{array}$ \\
\hline Spin-off & & $\begin{array}{c}-0.65^{\mathrm{b}} \\
(0.27)\end{array}$ & $\begin{array}{c}-0.53^{\mathrm{a}} \\
(0.27)\end{array}$ & $\begin{array}{r}-0.53^{\mathrm{a}} \\
(0.28)\end{array}$ \\
\hline Academic startup (post-1997) & $\begin{array}{r}-1.08^{b} \\
(0.54)\end{array}$ & $\begin{array}{r}-0.93^{\mathrm{a}} \\
(0.56)\end{array}$ & $\begin{array}{r}-0.76 \\
(0.56)\end{array}$ & $\begin{array}{r}-0.73 \\
(0.56)\end{array}$ \\
\hline Spin-off-regular & $\begin{array}{r}-0.54^{\mathrm{a}} \\
(0.33)\end{array}$ & & & \\
\hline Spin-off- $-\mathrm{PhD}$ & $\begin{array}{r}-0.64^{\mathrm{a}} \\
(0.34)\end{array}$ & & & \\
\hline Founder is patenting & & $\begin{array}{c}-0.66^{\mathrm{b}} \\
(0.31)\end{array}$ & & \\
\hline Inventors with $\mathrm{PhD}$ (pre-entry) & & & $\begin{array}{c}-0.60^{\mathrm{b}} \\
(0.27)\end{array}$ & $\begin{array}{c}-0.50^{\mathrm{a}} \\
(0.27)\end{array}$ \\
\hline No. of patents (pre-entry) & & $\begin{array}{r}-0.02 \\
(0.02)\end{array}$ & $\begin{array}{l}0.01 \\
(0.02)\end{array}$ & \\
\hline No. of inventors (pre-entry) & & & & $\begin{array}{r}-0.02 \\
(0.04)\end{array}$ \\
\hline Constant & $\begin{array}{r}-2.60^{c} \\
(0.24)\end{array}$ & $\begin{array}{c}-2.41^{\mathrm{c}} \\
(0.24)\end{array}$ & $\begin{array}{r}-2.56^{\mathrm{c}} \\
(0.02)\end{array}$ & $\begin{array}{c}-2.57^{\mathrm{c}} \\
(0.24)\end{array}$ \\
\hline Duration & $\begin{array}{r}-0.01 \\
(0.02)\end{array}$ & $\begin{array}{r}-0.00 \\
(0.02)\end{array}$ & $\begin{array}{c}-0.01 \\
(0.24)\end{array}$ & $\begin{array}{r}-0.00 \\
(0.02)\end{array}$ \\
\hline Time at risk & 1943 & 1943 & 1943 & 1943 \\
\hline Events & 78 & 78 & 78 & 78 \\
\hline Firms & 184 & 184 & 184 & 184 \\
\hline $\log$ Lik & -190.2 & -186.7 & -185.5 & -185.4 \\
\hline
\end{tabular}


working conditions (Reynolds et al. 2002; Buenstorf 2009). ${ }^{8}$ We also control for the firm's overall patent stock at entry (measured in the post-entry year to allow for lags in patent application). We obtain a significantly negative coefficient estimate for the founder patent variable, suggesting that opportunity entrepreneurship is systematically related to firm performance. In contrast, the overall patent stock at time of entry has no discernible effect on longevity.

The final two hazard rate models (Models 6 and 7 in Table 4) address the role of inventors with completed doctoral training. To limit endogeneity concerns, we again focus on early patents (entry year + 1). Controlling for the firm's overall patent stock at entry (Model 6) or the overall number of inventors (Model 7), our estimates point to a systematic link between early hires of doctorate-holding $R \& D$ staff and firm performance (coefficient estimates are significant at the 5 and $10 \%$ levels, respectively). The hazard of academic startups is most strongly affected by accounting for inventors with doctoral degrees. The implied effect of being an academic startup is reduced by about one-third (Model 7 vs. Model 3) and the estimated coefficient is no longer significant. In contrast, the coefficient estimated for spin-offs is reduced by less than $10 \%$, and that of diversifiers by about $15 \%$. This suggests that among all entrants, (late) academic startups benefitted most from hiring of R\&D staff who had received doctoral training at German universities.

\subsection{Further evidence on differences between types and cohorts of entrants}

Thus far, our empirical results indicate that academic startups fared better in the post-1997 period of the German laser industry than before, and that inventors with doctoral training contributed to the performance of entrants in this industry. While our research design does not allow for causal inference, these findings are consistent with a better utilization of scientific knowledge after the governance of university-industry was

\footnotetext{
${ }^{8}$ Some diversifiers are small and of young age when they enter the laser industry, and the available evidence suggests that their founders are still active at the time of entry into lasers. In these cases the prior patenting activity of founders is also included in the "opportunity entrepreneur" measure.
}

changed. ${ }^{9}$ In this subsection, we provide further pieces of evidence indicating that the German laser industry became more "scientific" after 1997.

In Table 5, we compare pre- and post-1997 academic startups to other entrants whose founders did, or did not, undergo doctoral training. The comparison shows that "non-academic" entrants (i.e., diversifiers, intra-industry spin-offs) were more likely to have founders with completed doctoral training after 1997. Academic startups entering in the post-1997 period were much more likely to patent, also prior to entry, than both their earlier peers and the other types of entrants. This stronger link between patenting and academic entrepreneurship after 1997 is in line with the findings of Czarnitzki et al. (2016). In contrast, the share of patentees decreased among the other types of entrants. Furthermore, while it is not surprising that academic entrepreneurs had more scientific publications than (doctorate-holding) founders of other types of entrants, again there is a notable increase from the first to the second period. Finally, the time elapsed between completing doctoral training and entry into the laser industry increased for both groups of entrepreneurs with doctoral degrees, with a constant difference of about 4 years between the groups. These patterns provide further evidence that the average quality of academic startups in the German laser industry increased after 1997.

Further differences are shown in Table 6, which lists the ten most common words found in the titles of patent applications of the different groups distinguished in Table $5 .{ }^{10}$ In spite of substantial heterogeneity, some changes in the prevalence of title words are noteworthy. First, "gas" is a common term in patents from all types of entrants before 1997, but more recently, it figures prominently only in the patents of non-academic firms. In contrast, "semiconductor" and "diode" have become more frequent over time, but only in the patents of academic startups and other entrants with doctorate-holding founders.

\footnotetext{
${ }^{9}$ The increased longevity of academic startups is also consistent with earlier results for EXIST-funded startups in the optical industries more generally (Kulicke and Kripp 2013).

${ }^{10}$ About $60 \%$ of all priority patents are in English. For the remaining ones, we identified the first family member with English title in the DOCDB patent family. More than $95 \%$ of all patent filings could be tracked in this way. Titles were standardized and English stop words were excluded. Frequent terms occurring in all subgroups were also excluded.
} 
Table 5 Comparison of market entrants before and after 1997

\begin{tabular}{|c|c|c|c|c|c|c|}
\hline & \multicolumn{2}{|c|}{ Academic startup } & \multicolumn{2}{|c|}{ Non-academic with $\mathrm{PhD}$ founder } & \multicolumn{2}{|c|}{ Non-academic other } \\
\hline & Post-1997 & Pre-1997 & Post-1997 & Pre-1997 & Post-1997 & Pre-1997 \\
\hline No. of entrants & 21 & 20 & 32 & 20 & 35 & 56 \\
\hline No. of (hard) exits & 3 & 12 & 3 & 8 & 9 & 32 \\
\hline Patenting & 0.90 & 0.40 & 0.50 & 0.70 & 0.43 & 0.68 \\
\hline Founder patenting & 0.52 & 0.35 & 0.41 & 0.30 & 0.14 & 0.18 \\
\hline No. of pat. before entry & 3.38 & 0.60 & 1.16 & 1.05 & 0.89 & 4.00 \\
\hline No. of founder publications & 6.34 & 0.93 & 1.38 & 0.14 & & \\
\hline Years to market entry after PhD & 9.82 & 7.47 & 13.79 & 11.29 & & \\
\hline
\end{tabular}

Rows one and two report number of firms, rows three to five report averages

Table 6 Most frequent terms used in laser patent titles

\begin{tabular}{|c|c|c|c|c|c|c|c|c|c|c|c|}
\hline \multicolumn{4}{|c|}{ Academic startup } & \multicolumn{4}{|c|}{ Non-academic with $\mathrm{PhD}$ founder } & \multicolumn{4}{|c|}{ Non-academic other } \\
\hline \multicolumn{2}{|l|}{ Post-1997 } & \multicolumn{2}{|l|}{ Pre-1997 } & \multicolumn{2}{|l|}{ Post-1997 } & \multicolumn{2}{|l|}{ Pre-1997 } & \multicolumn{2}{|l|}{ Post-1997 } & \multicolumn{2}{|l|}{ Pre-1997 } \\
\hline Term & Freq. & Term & Freq. & Term & Freq. & Term & Freq. & Term & Freq. & Term & Freq. \\
\hline Optical & 47 & Gas & 79 & Light & 49 & Gas & 35 & Optical & 13 & Semiconductor & 716 \\
\hline Semiconductor & 40 & Excimer & 76 & Beam & 47 & Optical & 24 & Processing & 13 & Beam & 506 \\
\hline Amplifier & 25 & Fluorine & 53 & Radiation & 43 & Diode & 18 & Light & 12 & Optical & 454 \\
\hline Cavity & 21 & Molecular & 53 & Component & 27 & Excimer & 15 & Material & 11 & Component & 365 \\
\hline Resonator & 21 & Discharge & 47 & Optical & 27 & Marking & 15 & Gas & 10 & Gas & 289 \\
\hline Beam & 20 & Beam & 33 & Producing & 25 & Light & 14 & Treatment & 10 & Optoelectronic & 289 \\
\hline Processing & 20 & Narrow & 25 & Using & 21 & Discharge & 13 & Beam & 9 & Producing & 262 \\
\hline Diode & 19 & Band & 21 & Energy & 15 & Glass & 13 & Radiation & 8 & Diode & 245 \\
\hline Optoelectronic & 18 & Control & 19 & Diode & 13 & Beam & 12 & Slab & 8 & Processing & 235 \\
\hline Radiation & 16 & Energy & 19 & Frequency & 13 & Ablation & 11 & Surgery & 8 & Machining & 234 \\
\hline
\end{tabular}

Fig. 2 Patent activities in the German laser industry (source: own compilation)

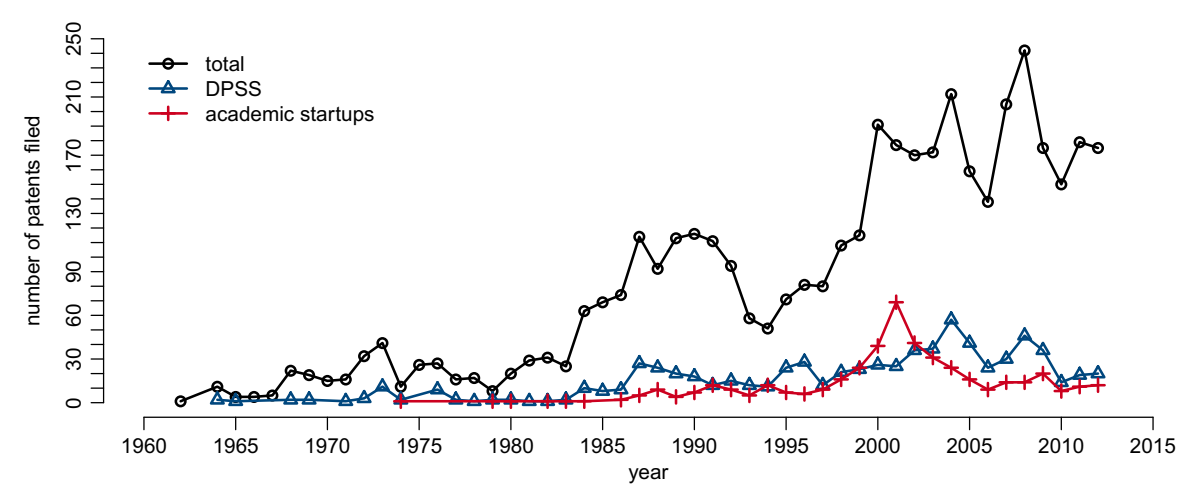


These appear to have shifted to the new laser types more rapidly. We moreover note that terms related to materials-processing lasers, such as "producing," "machining," "material," or "ablation," are not found among the top ten title words of academic startups at any time. Instead, their titles are more likely to refer to specifics of laser design, such as "cavity," "resonator," or "beam," particularly in the post-1997 period.

Finally, in light of the crucial role that Bhaskarabhatla and Klepper (2014) attribute to the DPSS laser in accounting for the recent evolution of the US laser industry, we also explore its importance for the German industry. Figure 2 shows the development of DPSS-related patents in relationship to overall patenting activities over time, as well as the patenting activities of academic startups. We employ the same measure for DPSS patents as Bhaskarabhatla and Klepper (2014), i.e., the IPC classes corresponding to USPTO 372 subclasses 40-50 (according to the USPTO concordance scheme ${ }^{11}$ ). Numbers of DPSSrelated patents are far from dominating overall patenting activities in Germany. Apparently, there is still significant innovation potential in other fields of laser technology, which is consistent with the fact that the DPSS laser did not choke entry into the German laser industry.

This does not mean that the DPSS laser was unrelated to entry. As a new and promising laser design, it should have provided entrants with entrepreneurial opportunities. DPSS patents can thus be interpreted as indicators of opportunities discovered by various types of firms in the laser industry. And if the performance of post-1997 academic startups was related to innovation, then they might stand out in their likelihood of DPSS patenting. To probe into this conjecture, we estimate a set of simple logit models pooling patenting activities over a firm's active years (conditional on that it was active in the time period when DPSS lasers were available) and having DPSS patenting as the dependent variable. Model 8 (Table 7) studies the likelihood of DPSS patenting for different types of entrants, using pre-1997 academic startups as the omitted reference group. We also control for the duration that a given firm was active in the laser industry, separating the years before and after emergence of the DPSS laser. We find that post-1997 academic startups

\footnotetext{
${ }^{11}$ https://www.uspto.gov/web/patents/classification/ (last access date: 2018.02.08).
}

Table 7 Entry in DPSS technology

Logit regression model

(Dependent variable: patent filed in DPSS associated IPCs)

(8)

(9)

(10)

\begin{tabular}{|c|c|c|c|}
\hline Diversifier & $\begin{array}{c}0.50 \\
(0.66)\end{array}$ & $\begin{array}{c}0.48 \\
(0.57)\end{array}$ & $\begin{array}{c}0.83 \\
(0.65)\end{array}$ \\
\hline Spin-off & $\begin{array}{c}0.92 \\
(0.66)\end{array}$ & & $\begin{array}{l}1.15^{\mathrm{a}} \\
(0.66)\end{array}$ \\
\hline Academic startup (post-1997) & $\begin{array}{l}2.58^{\mathrm{c}} \\
(0.79)\end{array}$ & $\begin{array}{c}2.57^{\mathrm{c}} \\
(0.72)\end{array}$ & $\begin{array}{c}2.69^{\mathrm{c}} \\
(0.85)\end{array}$ \\
\hline Spin-off_regular & & $\begin{array}{l}1.31^{\mathrm{a}} \\
(0.67)\end{array}$ & \\
\hline Spin-off-PhD & & $\begin{array}{c}0.85 \\
(0.68)\end{array}$ & \\
\hline Opportunity entrepreneur & & & $\begin{array}{c}1.32^{\mathrm{c}} \\
(0.42)\end{array}$ \\
\hline Years active post-DPSS & $\begin{array}{c}0.02 \\
(0.03)\end{array}$ & $\begin{array}{c}0.03 \\
(0.03)\end{array}$ & $\begin{array}{c}0.02 \\
(0.03)\end{array}$ \\
\hline Years active pre-DPSS & $\begin{array}{r}-0.08^{c} \\
(0.03)\end{array}$ & $\begin{array}{r}-0.09^{c} \\
(0.03)\end{array}$ & $\begin{array}{r}-0.09^{\mathrm{c}} \\
(0.03)\end{array}$ \\
\hline Constant & $\begin{array}{r}-1.63^{\mathrm{b}} \\
(0.75)\end{array}$ & $\begin{array}{r}-1.69^{b} \\
(0.73)\end{array}$ & $\begin{array}{r}-2.17^{\mathrm{c}} \\
(0.74)\end{array}$ \\
\hline Firms & 168 & 168 & 168 \\
\hline $\log \mathrm{Lik}$ & -88.34 & -87.19 & -82.93 \\
\hline Akaike Inf. Crit. & 188.68 & 188.37 & 179.86 \\
\hline
\end{tabular}

Robust standard errors in parentheses

${ }^{\mathrm{a}} p<0.1 ;{ }^{\mathrm{b}} p<0.05 ;{ }^{\mathrm{c}} p<0.01$

were most likely to have DPSS patents, whereas there are no significant differences among the other types of entrants. Earlier entrants were less likely to patent DPSS technology. Model 9 separates spin-offs by whether they have founders with doctoral training or not, finding that, if anything, the latter were more active in the DPSS field. Finally, in Model 10, we again use founder-invented patents before the time of entry as a proxy of opportunity entrepreneurship. This variable indeed helps predict DPSS patenting. It also changes the reference group of the analysis, which now consists of those early academic startups that were not based on opportunity (according to our proxy), as well as the small group of entrants with other or unknown backgrounds. Compared to this group, the coefficient estimate for spin-offs turns positive and marginally significant. We conclude from this set of models that post-1997 academic startups 
were disproportionately likely to exploit the opportunities opened up by the DPSS laser. This provides further evidence consistent with the conjecture that these firms were more capable than their earlier peers.

\section{Concluding remarks}

The laser industry has received substantial attention in the literature on industry evolution. One reason is that, in contrast to the life cycle pattern observed in many other industries, for decades, no shakeout was observed in the US laser industry or in its German counterpart. In addition, intra-industry spin-offs were numerous and tended to perform well in both countries. In this article, we focused on the recent evolution of the German laser industry. Our main interest was to trace how scientific knowledge, transferred to the laser industry through academic entrepreneurship and the labor mobility of inventors with doctoral training, affected entry and survival in the population of laser producers.

We found that the competitive performance of academic startups increased over time. The available evidence also suggests that they became more innovative and disproportionately accounted for patents in the novel DPSS lasers. These developments took place after the governance of university-industry relations changed in Germany, notably after support for academic entrepreneurs was stepped up and new infrastructure was provided for university technology transfer. However, our empirical study is not designed as a program evaluation able to identify causal effects, and we also lack detailed data on the US laser industry allowing for a systematic comparative analysis. We thus consider our findings as no more than suggestive regarding the link to policy changes, and we refer to the USA only because it provides us with a benchmark to assess the German development.

We moreover traced the role of doctoral training as a source of firm capabilities in the laser industry. According to our findings, inventors with doctoral training are associated with higher firm performance, and recent academic startups seem to have been most successful in harnessing the scientific knowledge of these inventors. In contrast, whether or not founders of intra-industry spin-off had completed doctoral training did not help account for the performance of their firms.
Do these findings help us understand why there still has not been a shakeout in firm numbers in the German laser industry? Academic startups clearly helped sustain the size of the firm population, and due to their increased longevity, the share of academic startups among all active firms has gradually gone up. However, academic startups only account for a minority of laser firms, and it would be far-fetched to attribute the absence of a shakeout exclusively to them. That the number of firms remained high in Germany also seems to reflect that the DPSS laser has not (yet) dominated the laser industry as much as it did in the USA. Other submarkets have remained competitive to date and continue to provide opportunities for entry. This includes submarkets for industrial materialsprocessing lasers, where German producers are among the global market leaders, but also new submarkets for ultra-high-frequency lasers for research applications.

We conclude by noting two important limitations of our analysis. First, data availability has limited our ability to trace the role of labor mobility in accounting for firm performance. While we could identify founder backgrounds and inventors with doctoral training, no information could be retrieved for non-patenting employees. We hope that future work will be able to do so using linked employer-employee data, but to date, this type of data is not available for industry studies of the type performed above. Second, our analysis relied on longevity in the laser industry as a measure of firm performance. As discussed above, this only provides a partial picture of firm performance, since surviving firms may differ widely in profitability and growth. Even though systematic information on profitability and growth could not be collected for the complete firm population, it is worth noting that none of the recent entrants into the laser industry appears to challenge the industry leaders. This holds for academic startups but also for intra-industry spin-offs. Specifically, there is a dearth of intra-industry spinoffs organized by top-level employees of leading firms, which according to prior research would be most likely to grow into new market leaders. Though there still are opportunities for entrepreneurial entry into the laser industry, apparently these are not exploited by those who would be best suited to do so. Judging from the earlier experience of other industries (Klepper 2016), the lack of high-level entrepreneurial activity does not bode well for the long-term prospects of the German laser industry. 
Funding information The authors received funding from the German Federal Ministry of Education and Research (BMBF) under grant number 16FWN001.

Open Access This article is distributed under the terms of the Creative Commons Attribution 4.0 International License (http:// creativecommons.org/licenses/by/4.0/), which permits unrestricted use, distribution, and reproduction in any medium, provided you give appropriate credit to the original author(s) and the source, provide a link to the Creative Commons license, and indicate if changes were made.

\section{References}

Albrecht, H. (1997). Laserforschung in Deutschland 1960-1970. University of Stuttgart, Unpublished Habilitation Thesis.

Beugelsdijk, S. (2007). Entrepreneurial culture, regional innovativeness and economic growth. Journal of Evolutionary Economics, 17(2), 187-210. https://doi.org/10.1007/978-3540-87910-7. arXiv:1011.1669v3.

Bhaskarabhatla, A., \& Klepper, S. (2014). Latent submarket dynamics and industry evolution: lessons from the US laser industry. Industrial and Corporate Change, 23(6), 13811415. https://doi.org/10.1093/icc/dtt060.

Blankenberg, A.K., \& Buenstorf, G. (2016). Regional coevolution of firm population, innovation and public research? Evidence from the West German laser industry. Research Policy, 45(4), 857-868. https://doi.org/10.1016/j. respol.2016.01.008.

Bromberg, J.L. (1991). The laser in America, 1950-1970. Cambridge: MIT Press.

Buenstorf, G. (2007). Evolution on the shoulders of giants: entrepreneurship and firm survival in the German laser industry. Review of Industrial Organization, 30(3), 179202. https://doi.org/10.1007/s11151-007-9132-1.

Buenstorf, G. (2009). Opportunity spin-offs and necessity spinoffs. International Journal of Entrepreneurial Venturing, 1(1), 22-40.

Buenstorf, G., \& Klepper, S. (2010). Why does entry cluster geographically? Evidence from the US tire industry. Journal of Urban Economics, 68(2), 103-114. https://doi.org/ 10.1016/j.jue.2010.03.005.

Buenstorf, G., Fritsch, M., Medrano, L.F. (2015). Regional knowledge, organizational capabilities and the emergence of the West German laser systems industry, 1975-2005. Regional Studies, 49(1), 59-75. https://doi.org/10.1080/ 00343404.2012 .711947$.

Cohen, W.M., \& Klepper, S. (1996). A reprise of size and R \& D. Economic Journal, 106, 925-951.

Czarnitzki, D., Doherr, T., Hussinger, K., Schliessler, P., Toole, A.A. (2016). Knowledge creates markets: the influence of entrepreneurial support and patent rights on academic entrepreneurship. European Economic Review, 86, 131146. https://doi.org/10.1016/j.euroecorev.2016.04.010.

Dahl, M.S., \& Klepper, S. (2015). Whom do new firms hire Industrial and Corporate Change, 24(4), 819-836. https://doi.org/10.1093/icc/dtv026.
Egeln, J., Dinges, M., Knie, A., Simon, D., Braun-Thürmann, H., Fryges, H., Müller, K. (2010). Evaluation des Existenzgründungsprogramms EXIST III. Baden-Baden: Nomos.

Fabian, C. (2011). Technologieentwicklung im Spannungsfeld von Industrie, Wissenschaft und Staat. Unpublished doctoral dissertation, Technical University Bergakademie Freiberg.

Frenken, K., \& Boschma, R.A. (2012). Economic development as a branching process, In: Buenstorf, G. (Ed.): Evolution, Organization and Economic Behavior (pp. 185-196). Cheltenham: Edward Elgar.

Fritsch, M., \& Medrano Echalar, L.F. (2015). New technology in the region-agglomeration and absorptive capacity effects on laser technology research in West Germany, 1960-2005. Economics of Innovation and New Technology, 24, 65-94. https://doi.org/10.1080/10438599.2014. 897861.

Fritsch, M., \& Wyrwich, M. (2014). The long persistence of regional levels of entrepreneurship: Germany, 19252005. Regional Studies, 48(6), 955-973. https://doi.org/10. 1080/00343404.2013.816414.

Gort, M., \& Klepper, S. (1982). Time paths in the diffusion of product innovations. The Economic Journal, 92(367), 630653.

Grupp, H. (2000). Learning in a science-driven market: the case of lasers. Industrial \& Corporate Change, 9(1), 143. https://doi.org/10.1093/icc/9.1.143.

Heblich, S., \& Slavtchev, V. (2014). Parent universities and the location of academic startups. Small Business Economics, 42(1), 1-15. https://doi.org/10.1007/s11187-013-9470-3. http://link.springer.com/article/10.1007/s11187-013-9470-3 http://link.springer.com/content/pdf/10.1007\%2Fs11187-0139470-3.pdf.

Helfat, C.E., \& Liebermann, M.B. (2002). The birth of capabilities: market entry and the importance of prehistory. Industrial and Corporate Change, 11(4), 725-760. https://doi.org/10.1093/icc/11.4.725. arXiv:1011.1669v3.

Hidalgo, C.A., Winger, B., Barabȧsi, A.L., Hausmann, R. (2007). The product space conditions the development of nations. Science, 317(5837), 482-487. https://doi.org/10. 1126/science.1144581. arXiv:0708.2090.

Jovanovic, B., \& MacDonald, G.M. (1994). The life cycle of a competitive industry. Journal of Political Economy, 102(2), 322-347. https://doi.org/10.1086/261934. -.

Klepper, S. (1996). Entry, exit and growth, and innovation over the product life cycle. American Economic Review1, 86(3), $562-583$.

Klepper, S. (1997). Industry life cycles. Industrial and Corporate Change, 6(1), 145-182. https://doi.org/10.1093/icc/6.1. 145.

Klepper, S. (2001). Employee startups in high-tech industries. Industrial and Corporate Change, 10(3), 639-674. https://doi.org/10.1093/icc/10.3.639.

Klepper, S. (2002). Firm survival and the evolution of oligopoly. The RAND Journal of Economics, 33(1), 37-61.

Klepper, S. (2016). Experimental capitalism: the nanoeconomics of american high-tech industries. Princeton: Princeton University Press.

Klepper, S., \& Sleeper, S. (2005). Entry by spinoffs. Management Science, 51(8), 1291-1306. https://doi.org/10.1287/ mnsc.1050.0411. 
Kulicke, M. (2014). 15 Jahre EXIST Existenzgründungen aus der Wissenschaft Entwicklung des Förderprogramms von 1998 bis 2013. Frauenhofer ISI, Karlsruhe.

Kulicke, M., \& Kripp, K. (2013). Ergebnisse und Wirkungen des Förderprogramms EXIST-Gründerstipendium. Frauenhofer ISI, Karlsruhe.

Lieberman, M.B., \& Montgomery, D.B. (2013). Conundra and progress: research on entry order and performance. Long Range Planning, 46(4-5), 312-324. https://doi.org/10. 1016/j.lrp.2013.06.005.

Marx, M., Strumsky, D., Fleming, L. (2009). Mobility, skills, and the Michigan non-compete experiment. Management Science, 55(6), 875-889.

Neffke, F., Henning, M., Boschma, R. (2011). How do regions diversify over time? Industry relatedness and the development of new growth paths in regions. Economic Geography, 87(3), 237-265. https://doi.org/10.1111/j.1944-8287.2011. 01121.x.

Nelson, R.R., \& Winter, S.G. (1982). An evolutionary theory of economic change. Cambridge MA: Belknap Press. arXiv: $1011.1669 \mathrm{v} 3$.

Peltoniemi, M. (2011). Reviewing industry life-cycle theory: avenues for future research. International Journal of Management Reviews, 13(4), 349-375. https://doi.org/10.1111/ j.1468-2370.2010.00295.x.

Perkmann, M., Tartari, V., Mckelvey, M., Autio, E., Brostróm, A., Este, P.D., Fini, R., Geuna, A., Grimaldi, R., Hughes, A., Krabel, S., Kitson, M., Llerena, P., Lissoni, F., Salter, A., Sobrero, M. (2013). Academic engagement and commercialisation: a review of the literature on university-industry relations. Research Policy, 42(2), 423-442. https://doi.org/10.1016/j.respol.2012.09.007.
Reynolds, P.D., Camp, S.M., Bygrave, W.D., Autio, E., Hay, M. (2002). Global entrepreneurship monitor: 2001 executive report. Tech. rep., Business Council for the United Nations.

Samila, S., \& Sorenson, O. (2011). Venture capital, entrepreneurship, and economic growth. Review of Economics and Statistics, 93(1), 338-349.

Schoen, A., Heinisch, D., Buenstorf, G. (2014). Playing the 'Name Game' to identify academic patents in Germany. Scientometrics, 101(1), 527-545. https://doi.org/10. 1007/s11192-014-1400-x.

Sleeper, S.D. (1998). The role of firm capabilities in the evolution of the laser industry: the making of a high-tech market. Carnegie Mellon University, $\mathrm{PhD}$ Dissertation.

Stinchcombe, A.L. (1965). Social structure and organizations. In March, J.G. (Ed.) Handbook of organizations (pp. 142193). Chicago: Rand Mc Nally.

Sutton, J. (1998). Technology and market structure: theory and history. Cambridge: MIT Press.

Trumpf Group. (2016). Annual report 2015/16. Ditzingen: Tech. rep.

Utterback, J.M., \& Suärez, F.F. (1993). Innovation, competition, and industry structure. Research Policy, 22(1), 1-21. https://doi.org/10.1016/0048-7333(93)90030-L.

Weterings, A., \& Marsili, O. (2015). Spatial concentration of industries and new firm exits: does this relationship differ between exits by closure and by M\&A Regional Studies, 49(1), 44-58. https://doi.org/10.1080/00343404.2012. 726708.

Zellner, C. (2003). The economic effects of basic research: evidence for embodied knowledge transfer via scientists' migration. Research Policy, 32(10), 1881-1895. https://doi.org/10.1016/S0048-7333(03)00080-5. 